\title{
Fermentabilitas Ruminal In Vitro pada Pakan Berbasis Jerami Padi Amoniasi dengan Suplementasi Tepung Bonggol Pisang dan Molases
}

\section{In Vitro Ruminal Fermentability on Ammoniated Rice Straw Based Diet With Supplementation of Banana Tree Root Ball and Molasess}

\author{
R. I. Rahayu*, A. Subrata, dan J. Achmadi \\ Fakultas Peternakan dan Pertanian, Universitas Diponegoro, Semarang, 50275 \\ *E-mail: irmafianita23@gmail.com \\ (Diterima: 23 April 2018; Disetujui: 5 Agustus 2018)
}

\begin{abstract}
ABSTRAK
Penelitian ini bertujuan mengkaji tepung bonggol pisang sebagai pengganti molases terhadap fermentabilitas pakan komplit berbasis jerami padi amoniasi secara in vitro. Penelitian menggunakan rancangan Uji T (T-Test) Independent Sample pada taraf signifikasi 5\% dengan 2 perlakuan dan 6 ulangan. Data yang diperoleh dianalisis menggunakan SPSS. Perlakuan yang digunakan pada penelitian ini yaitu (T1: pakan komplit 98\% + molases 2\%) dan (T2: pakan komplit 97,37\% + tepung bonggol pisang 2,65\%). Hasil penelitian menunjukkan bahwa penggantian molases dengan bonggol pisang pada pakan komplit berbasis jerami padi amoniasi secara in vitro tidak memberikan pengaruh yang berbeda $(\mathrm{p}>0,05)$ terhadap rerata produksi $\mathrm{NH}_{3} \mathrm{~T} 1(2,39 \mathrm{mM})$ dan $\mathrm{T} 2(2,31 \mathrm{mM})$, konsentrasi VFA total T1 $(58,33 \mathrm{mM})$ dan T2 $(63,33$ $\mathrm{mM})$, asam asetat T1 $(71,80 \%)$ dan T2 (72,22\%), asam propionat T1 $(20,67 \%)$ dan T2 $(21,84 \%)$, asam butirat T1 $(7,26 \%)$ dan $\mathrm{T} 2(6,27 \%)$, rasio $\mathrm{C}_{2} / \mathrm{C}_{3}$ pada $\mathrm{T} 1(3,45)$ dan $\mathrm{T} 2(3,32)$, kecernaan bahan kering $\mathrm{T} 1$ $(73,34 \%)$ dan T2 (72,51\%) dan kecernaan bahan organik T1 (80,80\%) T2 dan (77,74\%). Berdasarkan hasil penelitian dapat disimpulkan bahwa bonggol pisang dapat menggantikan molases sebagai sumber RAC pada pakan komplit berbasis jerami padi amoniasi.
\end{abstract}

Kata kunci: amoniasi, bonggol pisang, fermentabilitas, in vitro, jerami padi, molases

\section{ABSTRACT}

The research was purposed to examined the banana tree root ball (BTRB) as source of RAC replacement of molasess to fermentability of complete feed based ammoniated rice straw by in vitro. The research was done with T-Test of independent sample at 5\% with 2 treatment and 6 replications and data were analysed using SPSS. The treatmens used in this study were (T1 : complete feed 98\%+ molasess 2\%) and (T2 : complete feed 97,35\% + BTRB 2,65\%). The research analyzed by using T-Test for independent sample at 5\% significancy. The results showed that, complete feed with ammoniated rice straw based with molasess and BTRB by in vitro did not different $(p>0,05)$ forward value of mean $\mathrm{NH}_{3}$ production $\mathrm{T} 1$ $(2,39 \mathrm{mM})$ and T2 (2,31 mM), total VFA concentration T1 (58,33 $\mathrm{mM})$ and T2 (63,33 $\mathrm{mM})$, acetic acid T1 (71,80\%) and T2 (72,22\%), propionic acid $T 1$ (20,67\%) and T2 (21,84\%), butyric acid $T 1$ (7,26\%) and T2 (6,27\%), ratio $C_{2} / C_{3}$ on $T 1(3,45)$ and $T 2(3,32)$, dry matter digestibility $T 1(73,34 \%)$ and $T 2(72,51 \%)$ and organic matter digestibility $T 1$ (80,80\%) T2 and (77,74\%). Based on the result of the research, it can be concluded that BTRB can replace molasess as non structural carbohydrate in the ammoniated rice straw based feed complete.

Keywords: ammoniated, banana tree root ball, fermentability, in vitro, molasess, rice straw 


\section{PENDAHULUAN}

Pakan merupakan faktor penting dalam usaha peternakan, oleh sebab itu perbaikan manajemen pakan sangat diharapkan untuk meningkatkan efisiensi usaha peternakan. Ternak ruminansia membutuhkan pakan serat yang berfungsi sebagai sumber energi, serta untuk menjaga fungsi normal rumen dan aktivitas mikrobia rumen. Pada musim kemarau, produksi hijauan sangat terbatas sehingga perlu pakan alternatif sebagai pengganti hijauan yaitu limbah pertanian salah satunya jerami padi. Produksi jerami padi setiap kali panen mampu menghasilkan sekitar 10-12 ton/hektar, tetapi pemanfaatan jerami padi sebagai pakan hanya mencapai $31-39 \%$, sedangkan yang dibakar atau dikembalikan ke sawah sebagai pupuk 36$62 \%$ dan sekitar 7-16\% digunakan untuk keperluan industri (Akbar, 2014). Jerami padi merupakan pakan berkualitas rendah, karena rendahnya kandungan protein dan karbohidrat non struktural serta tingginya kandungan serat kasar, sehingga mempengaruhi nilai kecernaan. Kandungan silika pada jerami padi menjadi faktor pembatas dari pemanfaatan jerami padi sebagai pakan ruminansia. Hal ini disebabkan karena silika bersama dengan lignin memperkuat dan memperkeras dinding sel, sehingga tidak dapat dicerna oleh mikroba rumen (Martawidjaja, 2003). Perlakuan amoniasi jerami padi bertujuan untuk memutus ikatan lignoselulosa dan lignohemiselulosa sehingga mampu meningkatkan kualitas jerami padi dan meningkatkan kecernaannya.

Pakan jerami padi yang diberi perlakuan amoniasi harus diangin-anginkan untuk menghilangkan amonia sebelum diberikan ke ternak agar tidak menimbulkan efek negatif bagi ternak yang menghirup amonia tersebut. Penggunaan jerami padi amoniasi sebagai pakan dapat meningkatkan sumber non protein nitrogen karena adanya urea yang digunakan dalam perlakuan amoniasi. Oleh sebab itu, penggunaan jerami padi amoniasi sebagai pakan harus diimbangi dengan karbohidrat mudah difermentasi atau readily available carbohydrate (RAC) untuk meningkatkan fermentabilitas pakan. RAC merupakan karbohidrat yang mudah tersedia atau didegradasi dalam rumen, sehingga cepat menyediakan produk berupa asam $\alpha$ keto hasil fermentasi karbohidrat yang digunakan untuk sintesis protein mikroba. Kecepatan ketersediaan sumber rantai karbon harus seimbang dengan kecepatan ketersediaan amonia sebagai sumber N. Penambahan karbohidrat pada pakan dapat meningkatkan aktivitas mikroba, laju pertumbuhan mikroba, dan laju degradasi substrat oleh mikroba rumen (Kurniawati, 2004). Karbohidrat yang digunakan dalam pakan yaitu onggok, gaplek, molases dan lain-lain.

Molases merupakan hasil samping industri gula yang memiliki komponen sukrosa dan gula pereduksi (Rafleliawati, 2016). Hartadi et al. (1986) kandungan nutrien dari molases yaitu $23 \%$ air, protein kasar 5,4\%, lemak kasar 3\%, serat kasar $10 \%$, abu $10,4 \%$ dan BETN $74 \%$. Suhada et al. (2016) menyatakan bahwa molases gula tebu memiliki karbohidrat yang sangat baik dalam rumen. Molases banyak dimanfaatkan sebagai tambahan ransum, perekat (binder), industri dalam fermentasi pakan dan lain-lain. Penggunaan molases dalam jangka waktu panjang dikhawatirkan akan sulit didapatkan karena banyaknya penggunaan molases saat ini. Sehingga perlu alternatif lain sebagai sumber karbohidrat mudah difermentasi dalam pakan. Salah satu alternatif sumber karbohidrat mudah difermentasi untuk menggantikan molases yaitu tepung bonggol pisang.

Bonggol pisang merupakan bagian bawah batang pisang pada akar yang berbentuk umbi. Bonggol pisang sebagai limbah pertanian dapat menjadi alternatif pengganti molases sebagai sumber karbohidrat non struktural (RAC). Bonggol pisang kering memiliki kandungan yaitu pati $76 \%$, kalori $425 \%$, protein $3,4 \%$, Ca $150 \%$, P $2 \%$, Fe $0,04 \%$, vitamin $4 \%$ dan air $20 \%$ (Solikhin et al., 2012). Dilihat dari kandungan patinya, maka tepung bonggol pisang berpotensi 
Tabel 1. Kandungan Nutrisi dan Komposisi Penyusun Ransum

\begin{tabular}{lrr}
\hline \multirow{2}{*}{ Bahan Pakan } & \multicolumn{2}{c}{ Perlakuan } \\
\cline { 2 - 3 } & $\mathrm{T} 1$ & $\mathrm{~T} 2$ \\
\hline Jerami Padi Amoniasi (\%) & 55,00 & 55,00 \\
Bekatul (\%) & 3,00 & 2,00 \\
Onggok (\%) & 5,50 & 5,20 \\
Bungkil Kedelai (\%) & 9,50 & 9,45 \\
Jagung Giling (\%) & 25,00 & 25,70 \\
Molases (\%) & 2,00 & - \\
Tepung Bonggol Pisang (\%) & - & 2,65 \\
\hline Total & 100,00 & 100,00 \\
\hline Kandungan Nutrien & & \\
Protein Kasar (PK) (\%) & 12,01 & 12,08 \\
Total Digestible Nutriens (TDN) (\%) & 60,00 & 60,00 \\
Bahan Ekstrak Tanpa Nitogen (BETN) (\%) & 47,94 & 46,85 \\
Serat Kasar (SK) (\%) & 23,99 & 24,14 \\
Neutral Detergent Fiber (NDF) (\%) & 68,71 & 71,08 \\
Non Fiber Carbohydrate (NFC) (\%) & 18,27 & 18,07 \\
\hline
\end{tabular}

untuk menggantikan molases sebagai sumber RAC. Pati dan selulosa yang terkandung pada batang dan bonggol pisang, merupakan sumber energi yang mudah dimanfaatkan oleh bakteri asam laktat (Sutowo et al., 2016). Penambahan sumber RAC pada pakan komplit berbasis jerami padi amoniasi diharapkan mampu meningkatkan pemanfaatan nitrogen oleh mikroba guna mengoptimalkan sintesis protein mikroba.

Penelitian ini dilakukan untuk mengkaji fermentabilitas pakan komplit berbasis jerami padi amoniasi dengan suplementasi tepung bonggol pisang dan molases secara in vitro. Hasil penelitian diharapkan sebagai informasi tentang pemanfaatan tepung bonggol pisang mampu menggantikan molases sebagai sumber RAC pada pakan komplit berbasis jerami padi amoniasi.

\section{METODE}

Materi yang digunakan dalam penelitian ini adalah pakan komplit dengan protein kasar (PK) 12\% dan total digestible nutrien (TDN) $60 \%$ (Tabel 1). yang disusun dari jerami padi amoniasi, bekatul, jagung giling, onggok, bungkil kedelai, molases dan tepung bonggol pisang dengan ukuran masing-masing 50 mesh. Cairan rumen dari kambing Jawarandu betina berfistula berumur 2-2,5 tahun yang diberi pakan rumput. Pelaksanaan penelitian terbagi menjadi 3 tahap.

\section{Pembuatan jerami padi amoniasi dan tepung bonggol pisang}

Pembuatan jerami padi amoniasi dengan metode Komar (1984) menggunakan kadar amonia sebesar 4\% yang diperam selama 21 hari. Kemudian diangin-anginkan dan digrinder. Pembuatan tepung bonggol pisang diperoleh dari bagian bawah batang pohon pisang yang tertutup permukaan tanah kemudian dicacah dan dikeringkan serta digrinder.

\section{Uji fermentabilitas pakan secara in vitro}

Variabel yang diamati meliputi $\mathrm{NH}_{3}$, volatile fatty acid (VFA) parsial, VFA total, kecernaan bahan kering (KcBK) serta kecernaan bahan organik (KcBO). Sampel pakan ditimbang sebanyak 0,550,56 g. Sampel pakan dimasukan ke tabung fermentor yang sudah berisi $40 \mathrm{ml}$ McDougall dan $10 \mathrm{ml}$ cairan rumen kambing. Selanjutnya diinkubasi pada suhu $39^{\circ} \mathrm{C}$ 
selama 3 jam pada kondisi anaerob. Setelah 3 jam dilakukan pemberhentian fermentasi dengan perendaman air es dan disentrifuge dengan kecepatan 3.000rpm selama 15 menit untuk memisahkan endapan dan supernatan. Supernatan digunakan untuk analisis $\mathrm{NH}_{3}$, VFA total dan VFA parsial.

Analisis $\mathrm{NH}_{3}$ dilakukan dengan menggunakan teknik mikrodifusi Conway. Perhitungan produksi $\mathrm{NH}_{3}$ dengan menggunakan rumus :

$\mathrm{NH}_{3}=\left(\mathrm{ml} \mathrm{H}_{2} \mathrm{SO}_{4}\right.$ titran $\left.\times \mathrm{N} \mathrm{H}_{2} \mathrm{SO}_{4} \times 1000\right) \mathrm{mM}$

Analisis VFA parsial dilakukan dengan menggunakan gas kromatografi (GC). VFA parsial cairan rumen dapat dihitung dengan rumus :

VFA Parsial $=\frac{\text { Luss Sempd }}{\text { Luss Stand } m \text { (mlli) }} \times$ Konsentrasi

Sedangkan VFA total dianalisis menggunakan metode destilasi uap. Perhitungan produksi VFA total menggunakan rumus :

VFA total $=($ titran blanko - titran sampel $) \times \mathrm{N} \mathrm{HCl}$ $\times 1000 / 5 \mathrm{mM}$

Analisis KcBK dan KcBO dilakukan dengan metode Tilley dan Terry (1963) yaitu sampel 0,55 - 0,56 g ditambahkan McDougall $40 \mathrm{ml}$ dan cairan rumen $10 \mathrm{ml}$, kemudian diinkubasi selama 48 jam pada suhu $39^{\circ} \mathrm{C}$ selama 3 jam pada kondisi anaerob. Setelah 48 jam inkubasi, disentrifuge dan residu yang diperoleh kemudian ditambahkan larutan pepsin $\mathrm{HCl}$ sebanyak $50 \mathrm{ml}$ dan dilakukan inkubasi kedua selama 48 jam (setiap 6 jam sekali dilakukan penggojogan. Kemudian dilakukan penyaringan dengan kertas Whatman 41 dan dilakukan pengovenan selama 24 jam pada suhu $105{ }^{\circ} \mathrm{C}$ untuk mengetahui nilai KcBK, setelah dioven kemudian ditanur pada suhu $600{ }^{\circ} \mathrm{C}$ selama 6 jam untuk mengetahui nilai KcBO. Kecernaan bahan kering dan kecernaan bahan organik dapat dihitung dengan rumus:

$$
\begin{aligned}
& \mathrm{KcBK}=\frac{\text { Berat BK Sarpod -(BK residu }- \text { BK Blarko })}{\text { BK Sempel }} \\
& \mathrm{KcBO}=\frac{\text { Berat BOSarroel }- \text { (BO residu }-\mathrm{BO} \text { Blarko) }}{\text { BO Sarmel }}
\end{aligned}
$$

\section{Analisis Data}

Analisis statistik uji banding Uji-t ( $t$-Test) Independent Sample pada taraf signifikasi $5 \%$ dengan 2 perlakuan dan 6 ulangan. Perlakuan yang digunakan pada penelitian ini yaitu (T1 : pakan komplit 98\% + molases 2\%) dan (T2 : pakan komplit 97,35\% + tepung bonggol pisang 2,65\%).

\section{HASIL DAN PEMBAHASAN}

Hasil penelitian tepung bonggol pisang sebagai pengganti molases pada pakan komplit berbasis jerami padi amoniasi terhadap konsentrasi $\mathrm{NH}_{3}$, produksi VFA total, proporsi VFA parsial (asam asetat, asam propionat, dan asam butirat), rasio $\mathrm{C}_{2} / \mathrm{C}_{3}$, kecernaan bahan kering dan kecernaan bahan organik secara in vitro disajikan pada Tabel 2 .

\section{Konsentrasi Amonia $\left(\mathrm{NH}_{3}\right)$}

Amonia merupakan hasil proses degradasi protein dan non protein nitrogen yang masuk ke dalam rumen ternak ruminansia. Konsentrasi amonia berkaitan dengan sintesis protein mikroba, karena mikroba dalam rumen memanfaatkan amonia sebagai sumber nitrogen utama untuk sintesis protein mikroba. Konsentrasi $\mathrm{NH}_{3}$ merupakan salah satu indikator untuk mengetahui fermentabilitas protein pakan, aktivitas mikroba dan populasi mikroba rumen. Konsentrasi $\mathrm{NH}_{3}$ antara T1 dan T2 menunjukkan hasil yang tidak berbeda $(\mathrm{P}>0,05)$. Hal ini berarti T1 dan T2 mempunyai pemanfaatan amonia yang sama sebagai sumber nitrogen oleh mikroba rumen untuk membentuk protein tubuhnya. Hal ini diduga sumber $\mathrm{N}$ dan kerangka karbon yang disusun pada pakan komplit hampir sama antara T1 dan T2. Dengan demikian, dapat dikatakan bahwa tepung bonggol pisang 
Vol. 20 (3): 166-174

Tabel 2. Hasil Fermentabilitas Pakan Komplit secara In Vitro

\begin{tabular}{lrrr}
\hline \hline \multirow{2}{*}{ Parameter } & \multicolumn{2}{c}{ Perlakuan } & \multirow{2}{*}{ SEM* } \\
\cline { 2 - 3 } & $\mathrm{T} 1$ & $\mathrm{~T} 2$ & 0,07 \\
\hline $\mathrm{NH}_{3}(\mathrm{mM})$ & 2,39 & 2,31 & 2,99 \\
VFA total $(\mathrm{mM})$ & 58,33 & 63,33 & 0,53 \\
Asam Asetat $(\%)$ & 71,80 & 72,22 & 0,42 \\
Asam Propionat $(\%)$ & 20,67 & 21,84 & 0,24 \\
Asam Butirat $(\%)$ & 7,26 & 6,27 & 0,09 \\
Rasio $\mathrm{C}_{2} / \mathrm{C}_{3}$ & 3,45 & 3,32 & 1,02 \\
KcBK $(\%)$ & 73,34 & 72,51 & 0,98 \\
KcBO $(\%)$ & 80,80 & 77,74 & \\
\hline
\end{tabular}

Keterangan: T1 (pakan komplit 98\% + molases 2\%)

T2 (pakan komplit 97,35\% + tepung bonggol pisang 2,65\%)

*Angka merupakan rata-rata nilai tengah \pm Standar Error

mampu berperan sebagai sumber energi dan kerangka karbon sebagaimana molases.

Hasil konsentrasi $\mathrm{NH}_{3}$ pada pakan komplit berbasis jerami padi amoniasi dengan penambahan molases dan penambahan tepung bonggol pisang masing-masing yaitu 2,39 $\mathrm{mM}$ dan 2,31 mM (Tabel 2). Rendahnya konsentrasi $\mathrm{NH}_{3}$ diduga karena sumber nitrogen yang terdapat dalam pakan rendah. Hasil konsentrasi $\mathrm{NH}_{3}$ pada penelitian ini lebih rendah dibandingkan dengan kajian penelitian dari Savitri et al. (2016) melaporkan bahwa pakan komplit yang disusun dengan PK 12,10\% TDN 60,09\% menghasilkan produksi $\mathrm{NH}_{3} 5,57 \mathrm{mM}$. Konsentrasi $\mathrm{NH}_{3}$ yang dibutuhkan untuk mendukung sintesis protein mikroba rumen secara optimal yaitu 3,57-7,14 mM (Sutardi, 1979). Konsentrasi $\mathrm{NH}_{3}$ cairan rumen dipengaruhi oleh protein yang dikonsumsi dan proses degradasi protein dalam rumen.

Sintesis protein mikroba akan optimal jika adanya sinkronisasi waktu pelepasan yang bersamaan antara sumber nitrogen dan kerangka karbon dalam rumen. Menurut Suwarno (2008) faktor yang mempengaruhi produksi $\mathrm{NH}_{3}$ dalam rumen yaitu lamanya pakan dalam rumen, karbohidrat dalam ransum, kelarutan dan jumlah pakan serta $\mathrm{pH}$ rumen.

\section{Produksi Volatile Fatty Acids (VFA) Total}

Volatile Fatty Acids (VFA) merupakan sumber energi utama ternak ruminansia yang berasal dari produk akhir fermentasi karbohidrat yang terdapat di dalam rumen. VFA berperan sebagai kerangka karbon bagi pembentukan protein mikroba. Hasil produksi VFA total pakan komplit memberikan nilai yang sama $(\mathrm{P}>0,05)$ antar $\mathrm{T} 1$ dan $\mathrm{T} 2$. Hasil VFA total dengan penambahan molases yaitu $58,33 \mathrm{mM}$ sedangkan penambahan bonggol pisang yaitu $63,33 \mathrm{mM}$ (Tabel 2) termasuk rendah. Sutardi (1980) menyatakan bahwa konsentrasi VFA yang dihasilkan oleh mikroba rumen pada kondisi yang normal yaitu berkisar antara $80-160 \mathrm{mM}$. Rendahnya konsentrasi VFA total salah satunya dapat dipengaruhi oleh jumlah karbohidrat non struktural yang tersusun pada pakan komplit. Kandungan non fiber carbohydrate (NFC) dalam pakan komplit yang disusun yaitu T1 $(18,27 \%)$ dan T2 (18,07\%) (Tabel 1). Pakan yang tersusun sebagian besar mengandung selulosa dan hemiselulosa, sehingga dalam waktu 3 jam inkubasi proses fermentasi produksi VFA masih relatif rendah. Hasil penelitian Arangsri et al. (2017) bahwa pakan komplit dengan kandungan NFC 29,70\% menghasilkan VFA total sebesar $100,89 \mathrm{mM}$, sedangkan pakan komplit dengan kandungan NFC 25,40\% menghasilkan VFA total sebesar $99,0 \mathrm{mM}$. Menurut Wijayanti (2012) tinggi rendahnya konsentrasi VFA dipengaruhi oleh tingkat fermentabilitas pakan, jumlah karbohidrat yang mudah larut, $\mathrm{pH}$ rumen, kecernaan 


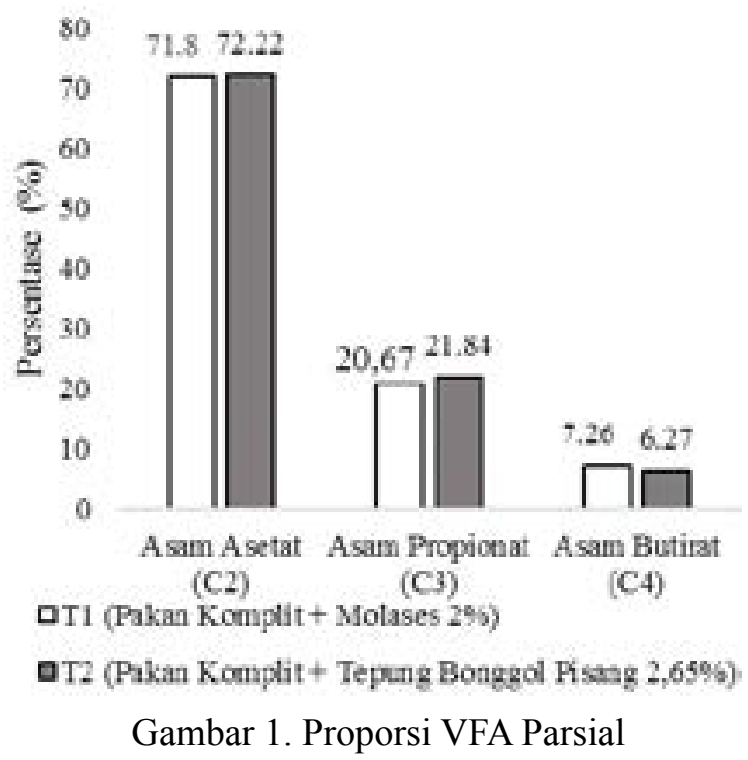

bahan pakan, jumlah pakan, serta jenis bakteri yang ada di dalam rumen. Karbohidrat non struktural (pati, pektin, dan gula sederhana) sangat cepat difermentasi dibandingkan dengan karbohidrat non struktural (selulosa, hemiselulosa dan lignin).

Widiasari (2010) melaporkan penelitian pada ransum pakan komplit dengan PK 12,01\% dan TDN 59,99\% secara in vitro menghasilkan VFA total sebesar 140,16 mM. Apabila semakin tinggi konsentrasi VFA maka sumber energi pada ternak optimum, hal ini mengindikasi bahwa proses fermentasi semakin efektif, namun apabila VFA terlalu tinggi dapat berdampak mengganggu keseimbangan sistem rumen (Sandi et al., 2015).

\section{Proporsi VFA Parsial dan Rasio $\mathbf{C}_{2} / \mathbf{C}_{3}$}

Hasil analisis uji $\mathrm{T}$ menunjukkan bahwa proporsi asam asetat, propionat dan butirat tidak berbeda antar perlakuan $(\mathrm{P}>0,05)$. Proporsi asam asetat pada TI yaitu $71,80 \%$ dan T2 yaitu $72,22 \%$ sedangkan proporsi asam propionat yang dihasilkan pada T1 yaitu 20,67\%, sedangkan T2 yaitu 21,84\% (Gambar 1). Asam asetat merupakan produk akhir dari fermentasi serat, sedangkan asam propionat merupakan produk akhir fermentasi gula dan pati. Arora (1995) menyatakan bahwa proposi asetat berkisar antara 50$65 \%$ dan propionat berkisar $18-24 \%$. Hasil penelitian ini menunjukkan bahwa asetat dan propionat berada dalam kisaran normal. Asam asetat digunakan oleh tubuh untuk sintesis asam lemak (lipid) dan merupakan prekusor utama proses lipogenesis pada jaringan adiposa. Asam asetat juga digunakan untuk metabolisme otot dan lemak tubuh. Sedangkan asam propionat merupakan prekusor pembentukan laktosa susu.

Rasio asam asetat dan asam propionat (rasio $\mathrm{C}_{2} / \mathrm{C}_{3}$ ) bertujuan sebagai tolok ukur efisiensi penggunaan energi ternak ruminansia dan kualitas produk yang dihasilkan. Hasil rasio $\mathrm{C}_{2} / \mathrm{C}_{3}$ pada penelitian tidak berbeda nyata antar perlakuan $(\mathrm{P}>0,05)$. Pada penelitian ini diperoleh hasil rasio $\mathrm{C}_{2} / \mathrm{C}_{3}$ yaitu $\mathrm{T} 1(3,45)$ dan T2 (3,32) (Tabel 2). Hasil penelitian ini lebih rendah dibandingkan dengan penelitian Uhi et al. (2006) bahwa rasio $\mathrm{C}_{2} / \mathrm{C}_{3}$ dengan perlakuan katalik berkisar 3,78-4,02, sedangkan hasil penelitian Putri (2013) menunjukkan bahwa dengan PK 14\% dan TDN 60\% menghasilkan rasio $\mathrm{C}_{2} / \mathrm{C}_{3}$ sebesar 3,80 . Rendahnya rasio $\mathrm{C}_{2} /$ $\mathrm{C}_{3}$ pada penelitian ini diduga karena banyaknya efisiensi penggunaan energi oleh ternak, sehingga kualitas produk yang dihasilkan lebih baik. Jika proporsi propionat meningkat maka proporsi asetat akan menurun, hal ini 
membuat rasio $\mathrm{C}_{2} / \mathrm{C}_{3}$ menjadi menurun. Rasio $\mathrm{C}_{2} / \mathrm{C}_{3}$ yang semakin rendah menunjukkan efisiensi dalam penggunaan energi yang lebih baik.

Hasil analisis proporsi asam butirat antar perlakuan tidak berbeda nyata $(\mathrm{p}>0,05)$. Hasil proporsi asam butirat pada pada T1 yaitu 7,26\% sedangkan T2 yaitu $6,27 \%$ (Gambar 1). Suwarno (2008) menyatakan bahwa proporsi asam asetat $\left(\mathrm{C}_{2}\right) 65 \%$, asam propionat $\left(\mathrm{C}_{3}\right) 20 \%$, asam butirat $\left(\mathrm{C}_{4}\right) 10 \%$, selain itu dihasilkan juga isobutirat $\left(\mathrm{iC}_{4}\right)$, isovalerat $\left(\mathrm{iC}_{5}\right)$, valerat $\left(\mathrm{C}_{5}\right)$ sekitar $5 \%$, serta gas metan $\left(\mathrm{CH}_{4}\right)$, dan karbondioksida $\left(\mathrm{CO}_{2}\right)$. Asam butirat merupakan sumber energi utama bagi ternak melalui proses glukoneogenesis (Mardalena, 2015). Pembentukan $\mathrm{C}_{4}$ memiliki sifat absorbsi yang lebih cepat dibandingkan dengan $\mathrm{C}_{2}$ dan $\mathrm{C}_{3}$, sehingga proporsi $\mathrm{C}_{4}$ dalam VFA juga sedikit (Pamungkas et al., 2008). Uhi et al. (2006) menyatakan bahwa pembentukan asam butirat erat kaitannya dengan pembentukan asam asetat, sehingga apabila konsentrasi asam asetat meningkat, maka adanya peningkatan pada konsentrasi asam butirat. Sebagian asam butirat yang terbentuk dimanfaatkan sebagai prekusor asam lemak air susu masuk ke dalam darah, dan digunakan sebagai sumber energi bagi jaringan tubuh.

\section{Kecernaan Bahan Kering (KcBK) dan Kecernaan Bahan Organik (KcBO)}

Hasil analisis statistik menunjukkan bahwa nilai $\mathrm{KcBK}$ tidak berbeda $(\mathrm{p}>0,05)$ antar perlakan T1 $(73,34 \%)$ dan T2 (72,51\%) (Tabel 2). Nilai KcBK kedua perlakuan relatif tinggi. Tingginya hasil kecernaan bahan kering diduga karena tingginya ketersediaan $\mathrm{N}$ dan kerangka karbon pada pakan yang dapat mengoptimalkan pertumbuhan mikroba sehingga semakin banyak pakan yang didegradasi. Hal tersebut sesuai dengan Lendrawati (2008) karbohidrat dalam pakan juga dapat mempengaruhi kecernaan bahan kering pada pakan, semakin tinggi jumlah karbohidrat mudah dicerna (non struktural), maka semakin tinggi nilai kecernaan pakan tersebut. Hasil penelitian Andini et al.
(2015) dengan rasio PK 12\% dan TDN 60\% pada pakan komplit berbasis limbah kelapa sawit mengasilkan nilai kecernaan bahan kering sebesar sebesar $51,22 \%$, sedangkan pakan komplit dengan kandungan PK 12,02 TDN 60,44\% menghasilkan nilai KcBK 43,31\%. Pengolahan bahan pakan dengan penambahan urea melalui proses amoniasi dapat meningkatkan kecernaan bahan kering dan kadar protein. Menurut Yanuarinto et al. (2015) kecernaan bahan kering jerami padi amoniasi yang mendapat perlakuan kimia selama 14, 21, dan 28 hari mengalami peningkatan sebesar $46,23 \%, 52,38 \%$ dan $56,11 \%$.

Nilai KcBO kedua perlakuan tidak berbeda $(\mathrm{p}>0,05)$ yaitu T1 $(80,80 \%)$, sedangkan T2 (77,74\%) (Tabel 2). Hasil ini relatif sama karena KcBK yang dihasilkan juga tidak berbeda antar perlakuan. Nilai $\mathrm{KcBO}$ berhubungan dengan nilai $\mathrm{KcBK}$, hal ini dikarenakan sebagian komponen hasil BK terdiri dari BO (Utomo, 2017). Persentase kecernaan bahan organik yang dihasilkan dari pakan komplit dengan PK 12,10\% TDN 60,09\% sebesar 57,61\% (Savitri et al., 2016).

Nilai KcBO yang relatif sama antar perlakuan selain disebabkan oleh komponen BO dan BETN, juga dipengaruhi oleh kandungan SK pakan perlakuan yang relatif sama. Setyadi et al. (2013) menyatakan bahwa nilai $\mathrm{KcBO}$ relatif tinggi dibandingkan dengan $\mathrm{KcBK}$, karena $\mathrm{BK}$ masih mengandung abu, sedangkan BO tidak mengandung abu. Adanya kandungan abu dapat menghambat tercernanya bahan kering pada pakan (Fathul dan Wajizah, 2010).

\section{KESIMPULAN}

Penggunaan tepung bonggol pisang dapat menggantikan molases sebagai sumber RAC atau karbohidrat mudah dicerna pada pakan komplit berbasis jerami padi amoniasi. 


\section{DAFTAR PUSTAKA}

Akbar, A. 2014. Degradasi Bahan Kering dan Bahan Organik In Vitro Ransum Berbahan Jerami Padi, Daun Gamal dan UMML. Fakultas Peternakan Universitas Hasanudin, Makasar (Skripsi).

Andini, W., A. Subrata dan L. K. Nuswantara. 2015. Pengaruh rasio energi protein ransum berbasis limbah perkebunan kelapa sawit terhadap kecernaan bahan kering, bahan organik dan serat kasar secara in vitro. J. Animal Agriculture. 4 (1) : $109-114$.

Arangsri, M., V. Pattarajinda, M. Duangjinda, J. Mungkalasiri, W. Angthong and J. K. Bernard. 2017. Impact of fermented total mixed rations on intake, VFA and methane production of dairy heifers. Indian. J. Anim. Res. B-749 : 1-5.

Arora, S. P. 1995. Pencernaan Mikroba Pada Ruminansa. Gadjah Mada University Press, Yogyakarta. (Diterjemahkan oleh B. Srigandono dan Retno Murwani).

Fathul, F. dan S. Wajizah. 2010. Penambahan mikromineral $\mathrm{Mn}$ dan $\mathrm{Cu}$ ransum terhadap aktivitas biofermentasi rumen domba secara in vitro. J. Ilmu Ternak dan Veteriner. 15 (1) : 9 - 15.

Hartadi, H., S. Reksohadiprodjo, S. Lebdosukojo dan A. D. Tilman. 1986. Tabel Komposisi Pakan untuk Indonesia. Gadjah Mada University Press, Yogyakarta.

Komar, A. 1984. Teknologi Pengolahan Jerami Pakan Ternak. Yayasan Dian Grahita, Bandung.

Kurniawati, A. 2004. Pertumbuhan mikroba rumen dan efisiensi pemanfaatan nitrogen pada silase Red Clover (Trifolium pratense cv Sabatron). Pusat Penelitian dan Pengembangan Teknologi Isotop dan Radiasi. BATAN, Jakarta. (Risalah Seminar Ilmiah Penelitian dan Pengembangan Aplikasi Isotop dan Radiasi).
Lendrawati, 2008. Kualitas Fermentasi dan Nutrisi Silase Ransum Komplit Berbasis Hasil Samping Jagung, Sawit, dan Ubi Kayu. Pascasarjana. Institut Pertanian Bogor, Bogor. (Tesis).

Mardalena. 2015. Evaluasi serbuk kulit nenas sebagai sumber antioksidan dalam ransum kambing perah Peranakan Etawah secara in Vitro. Jurnal IlmuIlmu Peternakan. 18 (1) : $14-21$.

Martawidjaja, M. 2003. Pemanfaatan jerami padi sebagai pengganti rumput untuk ternak ruminansia kecil. Wartazoa. 13 (3) : $119-127$.

Pamungkas, D., Y. N. Anggraeni, Kusmartono dan N. H. Krishna. 2008. Produksi asam lemak terbang dan amonia rumen sapi bali pada imbangan daun Lamtoro (L. Leucocephala) dan pakan lengkap yang berbeda. Seminar Teknologi Peternakan dan Veteriner, Malang.

Putri, L. D. N. A. 2013. Pengaruh Imbangan Protein dan Energi Pakan Terhadap Produk Fermentasi Di Dalam Rumen dan Protein Mikroba Rumen Pada Sapi Madura Jantan. Fakultas Peternakan dan Pertanian Universitas Diponegoro, Semarang (Skripsi).

Rafleliawati, P., Surahmanto, dan J. Achmadi. 2016. Efek pemanasan pada molases yang ditambahkan urea terhadap ketersediaan $\mathrm{NH}_{3}$, volatile fatty acid dan protein total secara in vitro. Jurnal Ilmu-Ilmu Peternakan. 26 (2) : 24 - 29.

Sandi, S., A. I. M. Ali, dan A. A. Akbar. 2015. Uji in vitro wafer ransum komplit dengan bahan perekat yang berbeda. Jurnal Peternakan Sriwijaya. 4 (2) : 7 $-16$.

Savitri, H. I., A. Muktiani, dan Sutrisno. 2016. Fermentabilitas pakan komplit dengan berbagai sumber protein yang terproteksi tannin dari daun Kaliandra (Calliandra calothyrsus) secara in vitro. Prosiding Seminar Nasional Kebangkitan Peternakan II. Semarang.

Setyadi, J. H., T. R. Rahardjo dan Suparwi. 
2013. Kecernaan bahan kering dan bahan organik tongkol jagung (Zea mays) yang difermentasi dengan Aspergillus niger secara in vitro. J. Ilmu Peternakan. 1 (1) : 170 - 175.

Solikhin, N., A. S. Prasetyo dan L. Buchori. 2012. Pembuatan bioetanol hasil hidrolisa bonggol pisang dengan fermentasi menggunakan Saccaromycess cereviceae. Jurnal Teknologi Kimia dan Industri. 1(1): 124-129.

Suhada, A. T., L. K. Nuswantara, E. Pangestu, F. Wahyono and J. Achmadi. 2016. Effect of synchronization of carbohydrate and protein supply in the sugarcane bagasse diet on microbial protein shyntesis in sheep. J. Indon. Trop. Anim. Agric. 4 (1) : 135 - 144.

Sutardi, T. 1979. Ketahanan protein bahan makanan terhadap degradasi mikroba rumen dan manfaatnya bagi produktivitas ternak. Prosiding Seminar Penelitian dan Pengembangan Peternakan. Lembaga Penelitian dan Pengembangan Pertanian. Bogor.

Sutardi, T. 1980. Landasan Ilmu Nutrisi. Jilid 1. Departemen Ilmu Makanan Ternak. Fakultas Peternakan, Institut Pertanian Bogor, Bogor.

Sutowo, I., T. Adelina dan D. Febrina. 2016. Kualitas nutrisi silase limbah pisang (batang dan bonggol pisang) dan level molases yang berbeda sebagai pakan alternatif ternak ruminansia. Jurnal Peternakan. 13 (2) : 41 - 47.

Suwarno, J. 2008. Pengaruh Rasio Pemberian Pakan Yang Berbeda Terhadap Produksi
VFA dan $\mathrm{NH}_{3}$ Rumen Serta Kapasitas Lambung Domba Jantan Lokal. Fakultas Peternakan Institut Pertanian Bogor, Bogor (Skripsi).

Tilley, J. M., and R. A. Terry. 1963. A two stage technique for in- vitro digestion of forage crops. J. Brit. Grassland Soc. 18 (2) : $104-111$.

Uhi, H.T., A. Parakkasi dan B. Haryanto. 2006. Pengaruh suplemen katalik terhadap karakteristik dan populasi mikroba rumen domba. Media Peternakan. 29 (1) : $20-26$.

Utomo, W. 2017. Kecernaan dan Efisiensi Pakan Komplit yang Mengandung Protein dan Energi yang Berbeda Pada Kambing Peranakan Etawa Dara. Fakultas Peternakan dan Pertanian Universitas Diponegoro, Semarang (Skripsi).

Widiasari, T. R. 2010. Kecernaan Pakan Komplit dengan Level Protein Kasar dan Energi Berbeda Secara In Vitro. Fakultas Peternakan Universitas Diponegoro, Semarang (Skripsi).

Wijayanti, E., F. Wahyono dan Surono. 2012. Kecernaan nutrien dan fermentabilitas pakan komplit dengan level ampas tebu yang berbeda secara in vitro. J. Anim. Agric. 1 (1) : 167 - 179.

Yanuarianto, O., M. Amin, M. Iqbal, dan S. D. Hasan. 2015. Kecernaan bahan kering dan bahan organik jerami padi yang difermentasi dengan kombinasi kapur tohor, Bacillus s., dan air kelapa pada waktu yang berbeda. Jurnal Ilmu dan Teknologi Peternakan Indonesia. 1 (1) : $47-52$. 